\title{
ATP IDENTIFICATION USING BALANCE OF PAYMENTS DATA: CASE OF THE CZECH REPUBLIC*
}

\author{
Jan Pavel ${ }^{a}(\mathbb{D})$ Jana Tepperováa
}

\begin{abstract}
Multinational enterprises apply aggressive tax planning (ATP) to optimize global tax liability usually by combining parameters of different tax systems in both national jurisdictions and double tax treaties. At a macroeconomic level, the implementation of various optimization schemes affects the given values of the balance of payments. By conducting econometric analysis, the present paper examines the extent to which selected optimization schemes can be traced in the Czech Republic's balance of payments. The results show that payments for counselling services and royalties flow mostly to locations with low corporate tax rates, which may suggest an attempt to shift the tax base. Moreover, dividend and interest yields tend to move to countries with high foreign direct investments (FDIs) and balanced ratios between FDIs received and made, indicating that they are only conduit (transit) countries through which profits are transferred to another destination.
\end{abstract}

Keywords: BEPS, balance of payments, corporate taxation, FDI, tax planning JEL Classification: H26, E62, F23

\section{Introduction}

In a globalized world, systems of corporate taxation have become more complex and vulnerable to tax abuse. Therefore, the Base Erosion and Profit Shifting (BEPS) project, launched by the G-20/OECD in 2013, plays an irreplaceable role in the fight against harmful tax practices. Use of structures allowing tax base erosion and shifting of profits is referred to as aggressive tax planning (ATP). Within an ATP strategy, multinational companies use sophisticated combinations of tax rules that result in a rather low effective tax liability.

* The present study is an output of a research project Fair corporate taxation: Measurement of the impact of the corporate profit shifting on the budget of the Czech Republic registered by the Czech Science Foundation under the registration number 18-14082S and a research project of institutional support at Faculty of Finance and Accounting at the University of Economics, Prague IP 100040.

a Prague University of Economics and Business, Prague, Czech Republic Email: pavelj@vse.cz, jana.tepperova@vse.cz 
Countries thus lose due tax revenues that, as most governments believe, belong to them since the corporations concerned operate on their territory. To ensure fair burden-sharing, state governments take measures to reduce the potential for aggressive tax planning. Alongside the OECD-led BEPS project, the European Union adopted independent ATAD and ATAD II directives. Other measures follow in the form of the so-called CADs (i.e., agreements on the exchange of information on tax issues) or not exclusively tax-oriented state aid rules. Moreover, governments strive to maintain sovereignty in their direct taxation policies, using tax systems to make their countries more attractive to investors. Countering ATP is thus an ongoing, complex legislative process, with space for engaging in ATP still being left.

ATP structures usually use parameters of national tax systems and EU guidelines in combination with double taxation treaties concluded by individual states. The European Commission identified seven basic ATP structures including, e.g., cross-border loans, hybrid mismatches, interest-free loans, patent boxes or cost-contribution agreements. The structures are usually based on cross-border dividend, interest and royalty flows, and on special rules (or their absence) for taxation of cross-border transactions. The basis of these structures is therefore in the parameters of tax systems and their combination covered by the regulations enshrined in double tax treaties.

When implementing different ATP schemes, funds are transferred between countries and recorded in respective items of the balance of payments. This allows, inter alia, gathering aggregate data on interest, dividends, cross-border financial services or intellectual property payments. Supposedly, countries with an atypical ratio of such payments can be used extensively within ATP structures. The rationale behind this is a particular configuration (or absence) of parameters of those countries' tax systems and/or their agreements on preventing double taxation.

The aim of the present paper is to determine to what extent selected optimization schemes can be identified, using the balance of payments data for the Czech Republic. In order to achieve this goal, we examine the data included in the CR balance of payments and the European Commission report (Study on Structures of Aggressive Tax Planning and Indicators, 2015), exploring the EU countries' tax system parameters.

The article comprises five sections. After an introduction, the relevant literature and state of the art of the issue are reviewed. In the third part, various taxation system parameters and balance of payments data are compared. The data description, models and results are presented in the next section, followed by the final part summarizing the conclusions.

Initial analysis was presented as a working paper at the conference Theoretical and Practical Aspects of Public Finance (Pavel and Tepperová, 2019). 


\section{Literature Review}

Aggressive tax planning consists in exploiting mismatches between tax systems and/or technical tax loopholes to reduce tax liability (effective taxation); see EC Recommendation, 2012. ATP is different from tax evasion, in general the latter being unambiguously unlawful. However, the borderline between tax planning, aggressive tax planning and tax evasion is not clear-cut (e.g., Oats and Tuck, 2019; Fuest and Riedel, 2009). The problem with clear specification of ATP is mainly given by the collision of technically legal behaviour of tax payers using combinations of legislation in a way that was not intended by the legislators. The intention of the legislators is even more complicated to specify in the international context as the countries are sovereign in their corporate income tax policy. In an effort to prevent such unintended behaviour, vague terms (such as "fair share of tax" or "ethical aspects") are used in the discussion to specify what is still within the law and what is considered aggressive (Datt, 2014). ATP strategies used by multinational enterprises (MNEs) affect the tax revenues of the countries involved. However, the specific effect for each country differs, depending on the country's position, for example, if it is used as a target or conduit country. Thus, tax competition (e.g., Deveraux et al., 2008) among countries might go against the proclaimed common efforts to suppress ATP entirely. An ATP structure is referred to as business organization of companies and their interrelationships using - in a lawful way - differences and ambiguities between tax regimes and their parameters. This can be done by shifting tax bases and profits, such activities being examined at both micro and macro levels. Microeconomic studies, drawing on firmlevel data, usually deal with tax base shifts and - selectively - transfer mispricing. Profit shifting through transfer prices is proven, e.g., by Fuest and Riedel (2012), Davies et al. (2015) or Vicard (2015). Nerudova et al. (2018) analyse data from the leaked Panama Papers documents, identifying tax evasion channels leading to people who put their money into an offshore tax haven. Recent studies have also shed light on the Czech Republic. Employing a microeconomic approach and corporate data, Janský and Kokeš $(2015,2016)$ highlight the domestic relevance of the BEPS initiative. In their 2015 article, they confirm that multinational enterprises with connections to companies in tax havens descend deeper into debt. In the follow-up paper (2016), they present evidence of taxable profit shifting through debt financing from the Czech Republic to Luxembourg, Switzerland and the Netherlands.

In terms of macroeconomics, the shifting of tax bases and taxable profits can be recorded indirectly via foreign direct investments (FDIs) and profitability. Within the BEPS project, the OECD lists FDI statistics alongside other data sources for analysing multinationals' profit shifts. The relationship between taxation and foreign direct 
investments was addressed by the UNCTAD report (2015a), highlighting the role of the so-called offshore investment hubs as well as that of investment policies within schemes of tax optimization. In the technical annex (UNCTAD, 2015b), the report maps out investment patterns regarding the tax policy pursued by the home, host and transit (conduit) countries, respectively, the investment being embedded in the so-called "offshore investment matrix". The role of investment in ATP is also reported by the International Monetary Fund (2014), which warns about unreasonably high foreign direct investments, expressed as share of GDP, in some countries the highest FDI-to-GDP ratio was exhibited by Luxembourg $(4,710)$, Mauritius $(2,504)$, the Netherlands (530), Hong Kong SAR (409), Cyprus (252), Ireland (171), Hungary (170), Switzerland (148), Malta (101) and Belgium (100). Exploring FDI parameters related to tax havens, Haberly and Wojcik (2014) trace an explicit link between colonial powers and their current or former colonies.

ATP practices are difficult to quantify, the published figures - i.e., rather rough estimates - being yielded by different research methodologies. Estimates made by the Tax Justice Network (2005), for example, suggested that USD 11,000 billion worth of assets were relocated into tax havens. Cobham and Jansky (2015) estimate that USD 660 billion ( $0.9 \%$ of world GDP) were transferred within the BEPS project in 2012. UNCTAD (2015c) notes that approximately $30 \%$ of cross-border investments are passed through a third country before landing in the destination. More recently, Bolwijn et al. (2018) have argued that investments flowing through conduit countries amount to between 30 and 50\%. There are more authors who recognize multinationals' potential to misuse a transfer company (conduit entity) for avoiding paying a fair share of taxes in their home country; see, e.g., Desai et al. (2003). According to Bradbury et al. (2018), who give an overview of studies spanning the years 2012-2015, assessing the fiscal impact of tax base erosion and profit shifting the global BEPS ranges from USD 80 to 647 billion.

Focusing on the situation in the Netherlands, Weyzig (2013) states that in 2009 multinational companies held FDIs worth about EUR 1,600 billion throughout the country. The Netherlands is an attractive transfer country, especially because of the extensive network of double tax treaties, allowing for the relocation of untaxed or low-tax investments and revenues. Sutherland and Matthews (2009) report that $47.5 \%$ of Chinese FDIs come from the Cayman Islands and the British Virgin Islands, which are considered tax havens. Van't Riet and Lejour (2014) examine the network of international double tax agreements and identify suitable countries that may become transfer (conduit) ones. They also believe that appropriate tax treaty provisions and repatriation of dividends from transfer countries can reduce the effective taxation of multinational enterprises by more than six percentage points. 
The European Commission's Study on Structures of Aggressive Tax Planning and Indicators (2015) introduces seven basic ATP structures, identifying parameters of tax systems that enable them to function properly. The EC followed up on its earlier study with the publication of the Aggressive Tax Planning Indicators report (2017), outlining ATP indicators and assessing whether the EU member states are on the right track.

The latter document asserts that each company involved in an optimization scheme has a role to play within an established national tax policy. The so-called target entity is the company that exports taxable profits. A low-tax entity, on the other hand, is the firm where profits are taxed. The company making use of the home country's favourable provisions of double tax treaties, or deliberately complicating and blurring the entire optimization structure, is the so-called conduit (transit) entity. Countries used in this way can be marked accordingly as target, low-tax and transit ones.

Multinational companies make use of various tools to optimize tax structures. An increase in the target company's costs occurs mainly by raising interest rates, royalties and service costs as well as by transfer pricing adjustments. The role of transfer prices in tax avoidance is described, for example, by Sikka and Willmott (2015). As Heckemeyer and Overesch (2013) report, up to one third of taxable income is estimated to be transferred via debt financing. The authors also conclude that transfer pricing and royalties are the main profit shifting channels. Grubert (2003) pointed to a substantial volume of in-house transactions between companies owning research and development intangible assets, highlighting the importance of intellectual property payments for tax planning. Similarly, Lipsey (2010) believes that legal and tax reasons lead to a strategic decision on a particular jurisdiction where intellectual property rights and intangible assets are to be relocated. Apart from technical parameters of tax systems, there is another separate area of tax optimization, namely tailor-made agreements with a tax authority - the so-called advance tax rulings (ATRs). Using the case of the LuxLeaks scandal revealed in 2014, Huesecken and Overesch (2015) demonstrated the impact of ATRs on effective tax rates of multinational corporations. Other analyses are better suited for some of the ATP strategies, typically for transfer pricing which is not generally caused by specific parameters of tax systems; these are mostly microeconomic analyses using firm-level data. We include the role of transfer mispricing by including a variable on services provided.

The proper functioning of tax optimization schemes is subject to dividend tax rules applied in target, low-tax and even in conduit country jurisdictions; in the latter one, only if the country is really used within the optimization structure. Furthermore, a country may be attractive due to its low statutory rates or income tax exemptions reducing the tax burden or, on the contrary, because of the absence of a strong general anti-tax avoidance rule (GAAR), control of foreign company (CFC) rules or exit taxation provisions. 
In terms of the given optimization structures, the country's tax-friendliness degree depends on the resulting combination of the above-mentioned push and pull factors.

Effective taxation is only one of the factors based on which the management of an MNE decide on how and from which country to operate its business (e.g., Tanzi, 1996; Laulajainen and Stafford, 1995). Location of business is decided according to specifics of its nature, and as Laulajainen and Stafford (1995) point out, there are many factors that influence location decisions; however, a few of them can be considered major, such as material inputs, availability of skilled and productive labour and its costs, quality of life, business climate, site characteristics, closeness to markets and governmental influences (including taxes).

\section{ATP Structures, Tax System Parameters and Balance of Payments Data}

As already mentioned, there are several ways to actually run ATP. Table 1 summarizes three basic models that can be applied using data from national balances of payments. The first method is the direct transfer of profits in the form of dividends and interest paid between related parties. This EU mechanism is based on directives allowing those funds to be exempt from corporate income tax; see relevant EU Council documents $(2003,2011)$. There are two subtypes of this model. According to the first one, the transferred profit remains in the given country. This is reasonable if it is possible to withdraw funds from the company with a lower tax burden than in the target country. Such an approach thus requires either a lower rate of personal income tax levied on dividends and profit shares, or an arrangement of the domestic tax system allowing tax-exempt sale of the company while it retains its capital. The second model subtype is closely associated with "conduit" countries, the profit being subsequently transferred to such a country that exhibits either lower taxes on natural person income, or lack of transparency, or both. This system takes advantage of inconsistencies in the provisions of double taxation treaties. Countries that are likely to serve as conduit ones usually have a noticeably balanced ratio between the volume of FDIs located abroad and those received; the volume of the former FDIs related to GDP even exceeds one hundred percent. The FDI ratio proves to be a good analytical indicator applied to quantification of the above aspects of the countries concerned (see below). The second strategy focuses on interest payments to unrelated parties. The other two ATP practices (models 3 and 4) focus on reducing the tax base in the target country, either through royalties or compliance costs since they provide more space for charging higher than usual prices. For these purposes, counselling services are particularly suitable, as they are difficult to be duly rewarded and so can be easily overestimated within the tax optimization process. Moreover, they are prone to fictitious 
financial reporting, failures to prove non-provision of a service being plentiful; these are, nevertheless, cases of unlawful tax evasion, thus reaching beyond the scope of ATP. Therefore, counselling services are an integral component of the following analysis.

Table 1: Parameters of ATP transactions and balance of payments data

\begin{tabular}{|c|c|c|c|c|}
\hline No. & $\begin{array}{l}\text { Type of ATP } \\
\text { strategy }\end{array}$ & $\begin{array}{c}\text { Possible } \\
\text { indicator based } \\
\text { on BOP data }\end{array}$ & $\begin{array}{l}\text { Indicator } \\
\text { of the recipient } \\
\text { country }\end{array}$ & $\begin{array}{c}\text { Parameter } \\
\text { of international law } \\
\text { allowing such strategy }\end{array}$ \\
\hline 1 & $\begin{array}{l}\text { Profit shifting } \\
\text { and base erosion } \\
\text { through dividends } \\
\text { and interest }\end{array}$ & $\begin{array}{l}\text { Outward dividends } \\
\text { Interest payment } \\
\text { to related persons }\end{array}$ & $\begin{array}{l}\text { For low-tax country - } \\
\text { low personal income tax } \\
\text { on dividends } \\
\text { For conduit country - } \\
\text { FDlratio* near } 1\end{array}$ & $\begin{array}{l}\text { Limitation of rights } \\
\text { to tax dividends and } \\
\text { interest in double } \\
\text { tax treaties and/or } \\
\text { by the EU Directive }\end{array}$ \\
\hline 2 & $\begin{array}{l}\text { Base erosion } \\
\text { through cost } \\
\text { of interest }\end{array}$ & $\begin{array}{l}\text { Interest payment } \\
\text { to unrelated } \\
\text { persons }\end{array}$ & $\begin{array}{l}\text { For low-tax country- } \\
\text { low EATR*** }\end{array}$ & - \\
\hline 3 & $\begin{array}{l}\text { Base erosion } \\
\text { through cost } \\
\text { of services }\end{array}$ & Import of services & $\begin{array}{l}\text { For low-tax country - } \\
\text { low EATR }\end{array}$ & - \\
\hline 4 & $\begin{array}{l}\text { Base erosion } \\
\text { through royalties }\end{array}$ & $\begin{array}{l}\text { Charges for use } \\
\text { of intellectual } \\
\text { property }\end{array}$ & $\begin{array}{l}\text { For low-tax country - } \\
\text { low EATR }\end{array}$ & $\begin{array}{l}\text { Limitation of rights } \\
\text { to tax royalties } \\
\text { in double tax treaties } \\
\text { and/or by an EU } \\
\text { directive }\end{array}$ \\
\hline
\end{tabular}

Note: * - for an explanation of this indicator, see below .

** - effective average corporate tax rate for the non-financial sector.

Source: own elaboration

Different existing taxation systems can facilitate ATP structures and practices. In addition to tax rates and base widths, national tax regimes vary in many other aspects. We use 33 parameters identified by the EC 2015 report (see above).

\section{Data and Methodology}

Based on the above discussion and the description of particular optimization mechanisms, regression analysis is carried out, aiming to identify the factors influencing outflows of funds from the Czech Republic to other EU countries. Research data are drawn from balances of payments over the period 2014-2016. The average values over that period are used, allowing cross-sectional regression to be used. The analysis focuses on the flows that can be significantly affected by tax optimization behaviour of economic subjects - payments of dividends and interest to related parties (DIVdeb and INTofFDIdeb, 
respectively), interest to unrelated parties (INTofPORTdebt), royalties (ROYdeb) and payments for counselling services (SERdeb). The employment of these variables allows identification of respective optimization schemes (1-4) for dividends and interest, counselling services, and royalties, respectively; see Table 1. In the case of dividend and interest payments, a performance indicator is designed to compare the value of outflows with the stock of the FDI. The given variables are PROFofDIV and PROFofDIVaINT. In the first case, it is the share of dividends paid and FDI stock, and in the second, the share of dividends and interest paid (to related persons) and FDI stock. Again, three-year (2014-2016) averages are used. These indicators are analogous to the Rate of Return indicator, but do not take into account retained earnings. This is because only flows that are leaving the country are relevant for the purposes of analysing aggressive tax planning, not the profits that remain.

Three types of explanatory variables are used in regression models. The first one is represented by two control variables (related to non-tax factors that may affect the abovementioned payment flows), namely

- $\quad$ FDIstock - the volume of funds invested by foreign entities in the Czech Republic in CZK (source: International Investment Position statistics), and

- GDPtotal - the size of the recipient country's economy expressed in EUR (source: Eurostat).

The second set of variables is represented by indicators describing the tax system in the recipient's country with a focus on such indicators that can provoke and/or enable creation of ATP structures, namely

- $\quad$ EATR - an effective average corporate tax rate for the non-financial sector; the figures were taken from the European Commission database (2018) in \%, and

- dummy variables P1-P33 that contain information on the lack of some tools for eliminating ATP; these variables were constructed using the data presented in the European Commission's 2015 report.

Finally, one indicator, which is calculated separately for each EU member country, represents the third type of the explanatory variable. This indicator is based on the data containing information about the stock of FDIs invested by the home country's entities (FDIout) and by foreign-owned ones in the respective country (FDIin). Both values are reported as shares of GDP and average values for 2014-2016 were used. The FDIratio indicator is calculated as follows:

$$
\text { FDIratio }=\frac{\text { FDIout }}{\text { FDIin }} * \text { FDIout }
$$


The objective of this indicator is to distinguish among countries that are FDI recipients, pure investors and potential conduit ones, the latter countries' FDIratio indicator reaching the highest values since FDIout/FDIin usually oscillates around 1, while FDIout often exceeds 1.

Functionality of the above indicator is illustrated in Figure 1, ranking the states used in the analysis according to their size. The lowest values are reported by post-communist countries who are net beneficiaries of FDI schemes. Most of the old EU member countries with a significantly positive investment balance are in the middle of the scale. High values are reported by states which are often referred to as conduit ones, through which profits are transferred. The highest values are indicated by Cyprus, which is due to the fact that the FDIin and FDIout rates are almost the same, both reaching ten times the GDP.

\section{Figure 1: EU member states ranked according to FDIratio}

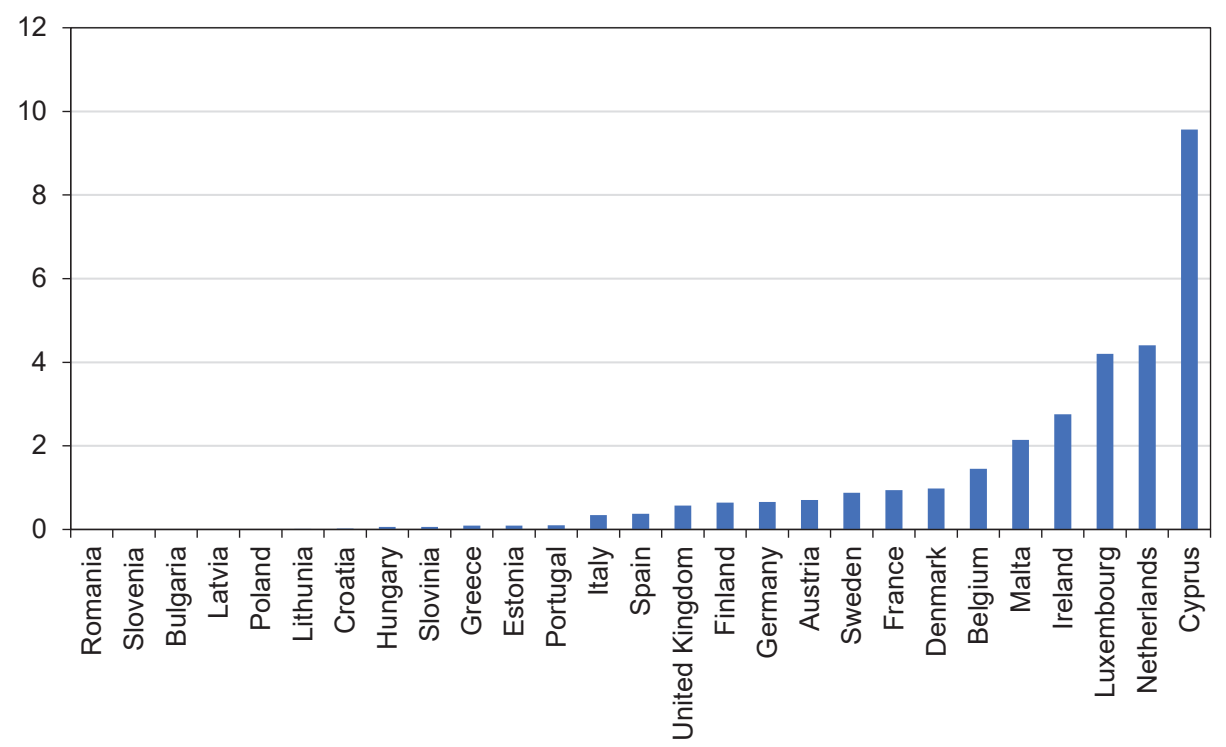

Source: own calculations

In terms of the assumed influence of explanatory variables on target ones, it seems obvious that dividends and interest paid to related entities should not be linked too closely to the volume of FDIs made. Further, FDIs are not expected to be sensitive to the effective tax rate (ETR), as the income is exonerated from taxation under the EU directive. On the other hand, interest for unrelated parties is not covered by the EU directive; thus, it is generally taxable and is expected to be sensitive to the ETR. Royalties and payments for counselling services, on the other hand, should be directed to low-tax destinations. 
Increased sensitivity to the tax rate of personal income from dividends and profit shares is presumed particularly in the case of dividends and interest payments from related parties. For the FDIratio index, an impact on dividends and interest is expected, thus indicating that this is the case of conduit (transit) countries.

We have also tested some other explanatory variables, such as personal income tax paid on dividends or number of double tax treaties. These were, however, consistently insignificant. Therefore, we have not included them in the final models.

Data from the Czech Republic's payment balances and from International Investment Position statistics (in case of FDIstock) for the period 2014-2016 are applied in the models constructed (Czech National Bank, 2018). For regression analysis, the data were averaged to eliminate annual fluctuations, those for Estonia, Lithuania and Greece having been excluded from the sample since some of the outflows show negative values. Altogether, 24 observations were always conducted. Basic descriptive statistics are listed in Table 2.

Table 2: Descriptive statistics of non-binary variables

\begin{tabular}{|c|c|c|c|c|c|c|}
\hline Variable & Units & Mean value & Median & Minimum & Maximum & Std. dev. \\
\hline DIVdeb & $\begin{array}{l}\text { CZK } \\
\text { million }\end{array}$ & $8,820.840$ & $1,028.910$ & 0.000 & $75,518.600$ & $16,886.200$ \\
\hline INTofFDIdeb & $\begin{array}{l}\text { CZK } \\
\text { million }\end{array}$ & 450.369 & 52.141 & 0.000 & $4,639.900$ & $1,032.430$ \\
\hline INTofPORTdeb & $\begin{array}{l}\text { CZK } \\
\text { million }\end{array}$ & 138.300 & 1.152 & 0.000 & $1,738.000$ & 346.400 \\
\hline ROYdeb & $\begin{array}{l}\text { CZK } \\
\text { million }\end{array}$ & 685.706 & 156.059 & 0.168 & $5,344.140$ & $1,389.040$ \\
\hline SERdeb & $\begin{array}{l}\text { CZK } \\
\text { million }\end{array}$ & $1,629.520$ & 517.543 & 8.981 & $16,781.700$ & $3,290.370$ \\
\hline PROFofDIV & ratio & 0.067 & 0.058 & 0.000 & 0.226 & 0.064 \\
\hline PROFofDIVaINT & ratio & 0.071 & 0.059 & 0.000 & 0.228 & 0.066 \\
\hline FDIstock & $\begin{array}{l}\text { CZK } \\
\text { million }\end{array}$ & $95,873.200$ & $20,927.800$ & -27.548 & $698,158.000$ & $168,196.000$ \\
\hline GDPtotal & $\begin{array}{l}\text { EUR } \\
\text { million }\end{array}$ & $547,227.000$ & $186,481.000$ & $10,180.100$ & $315,975,000,000.000$ & $838,426.000$ \\
\hline EATR & $\%$ & 21.178 & 19.600 & 9.000 & 38.300 & 6.985 \\
\hline FDIratio & ratio & 1.151 & 0.376 & 0.000 & 9.564 & 2.072 \\
\hline
\end{tabular}

Source: own calculations 


\subsection{Models}

In the empirical research undertaken, three groups of models were estimated using regression analysis; see the model outcomes in Tables 3-5. Reduced models are presented, employing only variables that are statistically significant at the $10 \%$ level at least. Non-linear relationships proved to be more informative for some models; therefore, the variables were used in logarithmic form. Owing to the heteroskedasticity problem, the models were estimated using a heteroskedasticity-robust standard error approach (White, 1980). In accordance with the procedures defined (Wooldridge, 2012), standard diagnostic instrument for analysing the possible multicollinearity (VIF) and a test for verification of normal residual distribution (the Chi-square Test of Goodness of Fit) were carried out, confirming that the proposed models satisfy the assumptions made.

In Tables 3 and 4, the explanatory variable is the average annual amount of funds leaving the Czech Republic (i.e., the five respective payments in logarithmic form) for particular countries in 2014-2016. In line with the assumptions, dividend and interest flows between related parties are not sensitive to the effective average tax rate (EATR), which results from their exemption under the relevant EU directives. For service payments, royalties and interest payments to unrelated parties, on the other hand, a statistically significant relationship was identified, the regression coefficient being negative. This means that these payments are directed to locations with lower corporate tax rates, which might indicate the use of optimization schemes 2, 3 and 4, respectively. A statistically significant relationship between the explained variable and the value of FDIs (1_FDIstocks) was shown in all five cases. This seems natural in the case of dividends and interest from related parties. For royalties and services, however, it may indicate that parent companies can transfer part of their investment income through those payments as well. Unfortunately, this cannot be verified directly, because the monitored balance of payments data are not divided according to the property connectivity of persons. For service payments and royalties, regression models have also shown a significant correlation with the size of the recipient country's economy (1_GDPtotal), i.e., their tendency to flow away to larger economies.

Interesting results are provided by the coefficient of the 1_FDIratio variables. The volume of dividends and interest paid to related parties increases with the growth of the 1_FDIratio indicator, larger amounts going to conduit countries, which receive on the contrary - the smallest influx of service payments. In terms of the dummy variables, no beneficial-owner test for reduction of withholding tax on dividends (P4), no CFC rules (P24), no rule to counter a mismatch in tax qualification of a domestic company between own state and a foreign state (P27) and no general or specific anti-avoidance rules to counter the model ATP structures (P32) proved to be statistically significant. 
Table 3: Regression model results for outflows of funds from the Czech Republic

\begin{tabular}{l|c|c|c|c}
\hline & \multicolumn{2}{|c|}{ I_DIVdeb } & \multicolumn{2}{c}{ I_INTofFDIdeb } \\
\hline Const & Coefficient & Standard error & Coefficient & Standard error \\
\hline I_FDIstock & $-11.544^{* * *}$ & 3.380 & $-10.131^{* * *}$ & 3.063 \\
\hline I_FDIratio & $1.811^{* * *}$ & 0.299 & $1.417^{* * *}$ & 0.273 \\
\hline P4 & $0.703^{* * *}$ & 0.219 & $0.674^{* * *}$ & 0.208 \\
\hline P32 & $3.923^{* * *}$ & 0.869 & - & - \\
\hline Adjusted $R^{\mathbf{2}}$ & - & - & $0.816^{* * *}$ & 0.914 \\
\hline
\end{tabular}

Note: I_ means log transformation of the variable.

${ }^{*} p<0.1 ;{ }^{* *} p<0.05$; ** $p<0.01$.

Source: own calculations

Table 4: Regression analysis results for shares of variables in fund outflows from the Czech Republic

\begin{tabular}{|c|c|c|c|c|c|c|}
\hline & \multicolumn{2}{|c|}{ I_INTofPORdeb } & \multicolumn{2}{|c|}{ I_SERdeb } & \multicolumn{2}{|c|}{ I_ROYdeb } \\
\hline & Coefficient & $\begin{array}{c}\text { Standard } \\
\text { error }\end{array}$ & Coefficient & $\begin{array}{c}\text { Standard } \\
\text { error }\end{array}$ & Coefficient & $\begin{array}{c}\text { Standard } \\
\text { error }\end{array}$ \\
\hline Const & 2.092 & 10.873 & $-4.928^{* *}$ & 1.999 & -1.876 & 2.415 \\
\hline I_FDIstock & $1.911^{* * *}$ & 0.2850 & $0.528^{* * *}$ & 0.073 & $0.588^{* * *}$ & 0.184 \\
\hline I_GDPtotal & - & - & $0.803^{* * *}$ & 0.157 & $0.812^{* * *}$ & 0.199 \\
\hline I_EATR & $-8.247^{* *}$ & 3.655 & $-1.496^{* * *}$ & 0.475 & $-2.950^{* *}$ & 1.293 \\
\hline I_FDIratio & - & - & $-0.133^{* *}$ & 0.048 & - & - \\
\hline P24 & - & - & $1.090^{*}$ & 0.523 & - & - \\
\hline P27 & $4.878^{* *}$ & 1.924 & - & - & - & - \\
\hline Adjusted $R^{2}$ & 0.610 & - & 0.860 & - & 0.670 & - \\
\hline
\end{tabular}

Note: I_ means log transformation of the variable.

${ }^{*} p<0.1 ;{ }^{* *} p<0.05 ;{ }^{* *} p<0.01$.

Source: own calculations

Finally, the last set of models is listed in Table 5, where the dependent variables are the share of dividends paid and FDI stock (PROFofDIV) and the share of dividends 
and interest paid (to related persons) and FDI stock (PROFofDIVaINT). The aim of the analysis was to find out which factors affect the narrowly defined FDI rate of return, considering only payments that leave the Czech Republic. Linear-log models where the explanatory variable is only the 1_FDIratio have the highest explanatory power. The estimated regression coefficients for the other independent variables tested proved to be statistically insignificant. The models suggest that while the lowest return is earned through investments made by post-communist countries, the highest narrowly defined rate of return is yielded in conduit countries.

Table 5: Regression analysis results for return on dividends and interest from related persons

\begin{tabular}{l|c|c|c|c}
\hline & \multicolumn{2}{|c|}{ PROFofDIV } & \multicolumn{2}{c}{ PROFofDIVaINT } \\
\hline & Coefficient & Standard error & Coefficient & Standard error \\
\hline Const & $0.092^{* * *}$ & 0.013 & $0.098^{* * *}$ & 0.012 \\
\hline I_FDIratio & $0.014^{* * *}$ & 0.003 & $0.015^{* * *}$ & 0.004 \\
\hline$R^{2}$ & 0.360 & - & 0.380 & - \\
\hline
\end{tabular}

Note: I_ means log transformation of the variable.

${ }^{*} p<0.1 ;{ }^{* *} p<0.05 ; * * * 0<0.01$.

Source: own calculations

\section{Conclusions}

Balance of payments data indicate tax optimization behaviour of economic entities, the Czech Republic serving as an example. In line with a theoretical analysis of potential optimization schemes, payments for royalties and consultancy services are directed to countries with low effective tax rates, which may suggest erosion of the tax base (optimization schemes 2 and 3). In terms of dividends and interest paid to affiliated persons, the models show high payment outflows to transit countries known as conduit ones (optimization scheme 1). Moreover, compared to other countries, these states' FDIs show a higher narrowly defined rate of return. According to general economic theory, however, profitability rates are supposed to equalize across countries. Apparently, investment income in non-conduit states is partly reduced by the flow of payments for consulting services rendered, which is not the case for conduit countries, the regression coefficient for the 1_FDIratio variable being negative. Higher levels of taxation in the latter countries can be partially eliminated by raising profits through service payments, thus also eroding the tax base, as is the case in the Czech Republic. 
In terms of national legal frameworks that may lead to ATP, the absence of certain tax rules (seen by the European Commission's 2015 report as key ones) showed except in four cases - no effect. The reason may be both their "rough" binary variable representation and the possibility that their influence can only be reflected in interaction with another variable. Analysis of this issue will be the subject of further research.

The study outcomes are consistent with the OECD (2015) document that recommends utilizing balance of payments data in exploring tax base erosion and profit transfers. The countries are clearly divided into target and conduit ones. The direction of dividend and interest flows mainly to conduit countries is indicative of appropriate double-taxation agreement provisions for preventing the so-called treaty shopping. This may be the case of passive income, as demonstrated by the present results. Counselling service contracts, on the other hand, do not contain special provisions to minimize taxes, and it is thus natural that they focus on low-tax jurisdictions.

Also, the results support previously published conclusions that profit shifting occurs through transfer mispricing, which is most reflected in the prices of counselling services as well as in interest rates and royalties; see Fuest a Riedel (2012), Heckemeyer and Overesch (2013), Davies et al. (2015), Vicard (2015) or Sikka and Willmott (2015). The findings presented here also refer to debt shifting practices identified in the Czech Republic by Janský and Kokeš (2016), who applied a microeconomic approach.

\section{References}

Bolwijn, R., Casella, B., Rigo, D. (2018). An FDI-driven Approach to Measuring the Scale and Economic Impact of BEPS. Transnational Corporations, 25(2), 107-143, https://doi.org/10.18356/c4f9fd3c-en

Bradbury, D., Hanappi, T., Moore, A. (2018). Estimating the Fiscal Effects of Base Erosion and Profit Shifting: Data Availability and Analytical Issues. Transnational Corporations, 25(2), 91-106, https://doi.org/10.18356/e1d7a8b4-en

Cobham, A., Janský, P. (2015). Measuring Misalignment: The Location of US Multinationals' Economic Activity versus the Location of Their Profits. ICTD. Working Paper No. 42, https://doi.org/10.2139/ssrn.3119824

Council of the EU (2003). Council Directive 2003/49/EC of 3 June 2003 on a Common System of Taxation Applicable to Interest and Royalty Payments Made between Associated Companies of Different Member States. Available at: https://eur-lex.europa.eu/ legal-content/EN/TXT/PDF/?uri=CELEX:32003L0049\&from=EN

Council of the EU (2011). Council Directive 2011/96/EU of 30 November 2011 on the Common System of Taxation Applicable in the Case of Parent Companies and Subsidiaries of Different Member States. Available at: https://eur-lex.europa.eu/legal-content/EN/TXT/ PDF/?uri=CELEX:32011L0096\&from $=$ en 
Czech National Bank (2018). Balance of Payments Statistics. Prague: Czech National Bank. Available at: https://www.cnb.cz/cs/statistika/platebni_bilance_stat/publikace_pb/ bezny_ucet_pb_tc/

Datt, K. H. (2014). Paying a Fair Share of Tax and Aggressive Tax Planning - A Tale of Two Myths. EJournal of Tax Research, 12(2), 410-432. Available at: https://search.proquest. com/docview/1674651839?accountid=17203

Davies, R. B., Martin, J., Parenti, M., et al. (2015). Knocking on Tax Haven's Door: Multinational Firms and Transfer Pricing. SSRN Paper No. ID2666947.

Desai, M. A., Foley, C. F., Hines, J. R. (2003) Chains of Ownership, Regional Tax Competition, and Foreign Direct Investment, in Herrmann, H., Lipsey, R., eds., Foreign Direct Investment in the Real and Financial Sector of Industrial Countries. Springer: Berlin, Heidelberg, pp. 61-98, https://doi.org/10.1007/978-3-540-24736-4_4

Devereux, M. P., Lockwood, B., Redoano, M. (2008). Do Countries Compete over Corporate Tax Rates? Journal of Public Economics, 92(5-6), 1210-1235, https://doi.org/10.1016/j. jpubeco.2007.09.005

European Commission (2012). Commission Recommendation of 6 December 2012 on Aggressive Tax Planning (2012/772/EU). Available at: https://op.europa.eu/en/publication-detail/-/ publication/fffoff5a-4451-11e2-9b3b-01aa75ed71a1/language-en

European Commission (2015). Study on Structures of Aggressive Tax Planning and Indicators. Final Report. WP No. 61-2015. Available at: https://ec.europa.eu/taxation_customs/sites/ taxation/files/resources/documents/taxation/gen_info/economic_analysis/tax_papers/ taxation_paper_61.pdf

European Commission (2017). Aggressive Tax Planning Indicators. Final Report. WP No. 71 2017. Specific Contract No. 5 TAXUD/2016/DE/319 Implementing the Framework Service Contract No. TAXUD/2015/CC/131 for the Provision of Economic Analysis in the Area of Taxation. Available at: https://ec.europa.eu/taxation_customs/sites/taxation/files/ taxation_papers_71_atp_.pdf

European Commission (2018). Data on Taxation. Effective Tax Rates, Non-financial Sector. Available at: https://ec.europa.eu/taxation_customs/business/ economic-analysis-taxation/data-taxation_en

Fuest, C., Riedel, N. (2009). Tax Evasion, Tax Avoidance and Tax Expenditures in Developing Countries: A Review of the Literature. Report. Oxford: Oxford University Centre for Business Taxation. Available at: https://assets.publishing.service.gov.uk/ media/57a08b3de5274a31e0000a66/60670_TaxEvasionReportDFIDFINAL1906.pdf

Fuest, C., Riedel, N. (2012). Tax Evasion and Tax Avoidance: The Role of International Profit Shifting. Oxford University Centre for Business Taxation. Working Paper No. 10/12.

Grubert, H. (2003). Intangible Income, Intercompany Transactions, Income Shifting, and the Choice of Location. National Tax Journal, 56(1), 221-242, https://doi.org/10.17310/ ntj.2003.1s.05 
Haberly, D., Wojcik, D. (2014). Tax Havens and the Production of Offshore FDI: An Empirical Analysis. Journal of Economic Geography, 15(1), 75-101, https://doi.org/10.1093/jeg/ Ibu003

Heckemeyer, J. H., Overesch, M. (2013). Multinationals' Profit Response to Tax Differentials: Effect Size and Shifting Channels. ZEW - Centre for European Economic Research. Discussion Paper No. 13-045, https://doi.org/10.2139/ssrn.2303679

Huesecken, B., Overesch, M. (2015). Tax Avoidance through Advance Tax Rulings - Evidence from the LuxLeaks Firms, https://doi.org/10.2139/ssrn.2664631

International Monetary Fund (2014). Spillovers in International Corporate Taxation. International Monetary Fund. Washington D.C. IMF Policy Paper No. 2014/071, https://doi.org/10.5089/9781498343367.007

Janský, P., Kokeš, O. (2015). Corporate Tax Base Erosion and Profit Shifting Out of the Czech Republic. Post-Communist Economies, 27(4). 537-546, https://doi.org/10.1080/14631377 .2015 .1084733

Janský, P., Kokeš, O. (2016). Profit-shifting from the Czech Multinational Companies to European Tax Havens. Applied Economic Letters, 23(16), 1130-1133, http://doi.org/10.1 080/13504851.2015.1137543

Lipsey, R. E. (2010). Measuring the Location of Production in a World of Intangible Productive Assets, FDI, and Intra firm Trade. Review of Income and Wealth, 56(1), S99-S110, https://doi.org/10.1111/j.1475-4991.2010.00385.x

Nerudova, D., Solilova, V., Litzman, M., et al. (2018). International Tax Planning within the Structure of Corporate Entities Owned by the Shareholder-individual through Panama Papers Destinations. Development Policy Review, 38(1), 124-139, https://doi.org/10.1111/dpr.12403

Nilsson, J.-E., Laulajainen, R., Stafford, H. A. (1996). Corporate Geography: Business Location Principles and Cases. Geografiska Annaler. Series B, Human Geography, 78(3), 183-185, https://doi.org/10.2307/490835

Oats, L., Tuck, P. (2019). Corporate Tax Avoidance: is Tax Transparency the Solution? Accounting and Business Research, 49(5), 565-583, https://doi.org/10.1080/00014788.2019.1611726

OECD (2015). OECD/G20 Base Erosion and Profit Shifting Project. 2015 Final Reports.

Executive Summary. Available at: https://www.oecd.org/ctp/beps-reports-2015executive-summaries.pdf

Pavel, J., Tepperová, J. (2019). FDI and Base Erosion and Profit Shifting from the Czech Republic. Working Paper presented at $24^{\text {th }}$ International Conference Theoretical and Practical Aspects of Public Finance, $12^{\text {th }}$ and $13^{\text {th }}$ April 2019, Prague. To be published in proceedings.

Sikka, P., Willmott, H. (2010). The Dark Side of Transfer Pricing: Its Role in Tax Avoidance and Wealth Retentiveness. Critical Perspectives on Accounting, 21(4), 342-356, https://doi.org/10.1016/j.cpa.2010.02.004 
Sutherland, D., Matthews, B. (2009). 'Round Tripping' or 'Capital Augmenting' OFDI? Chinese Outward Investment and the Caribbean Tax Havens. Paper prepared for Leverhulme Centre for Research on Globalisation and Economic Policy (GEP), University of Nottingham 14th and 15th January.

Tanzi, V. (1996). Globalization, Tax Competition and the Future of Tax Systems. International Monetary Fund. Working Paper No. 1996/141, https://doi.org/10.5089/ 9781451928280.001

Tax Justice Network (2005). The Price of Off Shore. Briefing Paper. Available at: https://www. taxjustice.net/cms/upload/pdf/Price_of_Offshore.pdf

UNCTAD (2015a). FDI, Tax and Development. The Fiscal Role of Multinational Enterprises: Towards Guidelines for Coherent International Tax and Investment Policies. UNCTAD Investment and Enterprise Division. Working Paper No. 3/26/2015.

UNCTAD (2015b). An FDI-driven Approach to Measuring the Scale and Economic Impact of BEPS. ANNEX II - Technical background paper accompanying the UNCTAD. Working Paper on „FDI, Tax and Development". UNCTAD Investment and Enterprise Division, Working Paper No. 3/26/2015.

UNCTAD (2015c). World Investment Report 2015: Reforming International Investment Governance [online]. Chapter V. International Tax and Investment Policy Coherence. New York and Geneva: UNCTAD NATIONS,_https://doi.org/10.18356/293b1525-en

Van't Riet, M., Lejour, A. (2014). Ranking the Stars: Network Analysis of Bilateral Tax Treaties. CPB. Discussion Paper No. 290.

Vicard, V. (2015). Profit Shifting Through Transfer Pricing: Evidence from French Firm Level Trade Data. Banque de France. Working Paper No. 555, https://doi.org/10.2139/ssrn.2614864

Weyzig, F. (2013). Tax Treaty Shopping: Structural Determinants of Foreign Direct Investment Routed through the Netherlands. International Tax and Public Finance, 20(6), 910-937, https://doi.org/10.1007/s10797-012-9250-z

White, H. (1980). A Heteroskedasticity-Consistent Covariance Matrix Estimator and a Direct Test for Heteroskedasticity. Econometrica, 48(4), 817-838, https://doi. org/10.2307/1912934

Wooldridge, J. M. (2012). Introductory Econometrics: A Modern Approach. Mason, Ohio: SouthWestern Cengage Learning. 